\title{
SOCIAL ASPECTS OF THE SUBURBANISATION STAGE IN THE AGGLOMERATION OF WARSAW
}

\author{
Andrzej Lisowski \\ Warsaw University, Faculty of Geography and Regional Studies \\ 00-927 Warsaw, ul. Krakowskie Przedm. 30, Poland \\ e-mail: alisowski@uw.edu.pl
}

\begin{abstract}
The study identifies the changes in the living conditions in the Agglomeration of Warsaw 1995-2001 and their impact upon the decentralisation process of the population and businesses. It has been confirmed that spatial re-distribution of people and jobs in suburban zone is affected by the living conditions in the areas, but the impact of land rent seems to be also important.
\end{abstract}

Key words: suburbanisation, living conditions, redistribution of population and businesses

\section{INTRODUCTION}

The purpose of the present report is to attempt an identification of spatial changes concerning the living conditions in the Agglomeration of Warsaw (pop. 2435 thou. 2001) in the years 1995-2001, and to verify the hypothesis that the living conditions do impact upon the differentiation of spatial re-distribution of places of residence and location of businesses (registered economic agents). Irrespective of the common verbal acceptance of the new middle-class myth of a house-with-a-garden, the inhabitants of the suburban zone do list until nowadays among the most acute inconveniences the shortages in the social and technical infrastructure within their respective areas of residence. The selection of the time frame of analysis was dictated by two factors. The period of study was beyond doubt a period of intensive structural changes, preceded by the period of economic recession, triggered by the introduction of the market economy at the turn of the 1990s. Of importance was also the availability of the comparative statistical data for the territorial units analysed ("gminas" - communes). 


\section{WHAT IS SUBURBANISATION?}

In the Polish scientific and planning terminology the notion of "metropolitan area" finds the closest counterpart in the form of "urban agglomeration", the latter encompassing the socalled central city (the metropolitan centre) and the smaller towns, neighbouring upon it, as well as the densely populated territories outside of towns (Gawryszewski et al., 1998). In the morphological sense an essential feature of the compact area of an agglomeration is constituted by the higher than average values of the characteristics, considered in the given socio-economic conditions to be the yardsticks of the narrowly or broadly conceived level of urbanisation - in the demographic, economic, social and landscape terms. In the functional sense, on the other hand, the essential characteristic is the nexus of functional component parts of the area, in which the role of the node (the dominating centre) falls usually upon the central city of the agglomeration.

It is still not easy to describe the notion of suburbanisation, and even less so - to convincingly justify its conditioning (Mieszowski, Mills, 1993; Bourne, 1996; Champion, 2001). The glossaries and dictionaries quote more often the terms of "suburb" and "urban sprawl" than "suburbanisation". A lack of clear distinction between urban and suburban raises the question of validity of studying "suburbanisation" as a distinctive phenomenon in more developed countries (Champion 2001, 150). This aspect of urban change is closely related with the dynamic aspect of the urban agglomeration. Agglomeration displays the tendency towards spreading, to spatial expansion, and at the same time to the internal restructuring in the course of its development. The notion of "suburbanisation" appears to have three elementary connotations, though they are strictly associated:

1. In the broad sense it means exactly the spread of the urban areas, in the physical and social sense, within the vicinity of the central city of agglomeration. More land area (rural areas, open areas) is converted to urban use or slightly urbanized areas becoming more intensively used (urbanisation of suburbs). The evaluation of this process is ambiguous. It creates the desired effects, but the negative consequences of the process of extension of urban areas in rural surroundings, as well as in central city (decline of city-centre) are being pointed out with the term of urban sprawl. This term is often used pejoratively to describe the disadvantageous changes and socio-spatial conflicts, resulting from the spontaneous extension of low density urban areas (Johnston et al., 2000, 783).

2. In the other sense "suburbanisation" is consider as a movement of different actors from central city, participating in the spread of urban areas around urban agglomeration. At the turn of $\mathrm{XX}^{\text {th }}$ century few city-winners were involved, but the list of participants spreading out, with rising average incomes and negative effects of congestion in central city. On the one hand, redistribution of population and jobs was the consequence of stabilisation of the administrative boundaries of the central city, and on the other hand, it resulted from the negative effects of the excess concentration of population and businesses within these boundaries.

3. The special sense of the notion of suburbanisation refers to the defined stage of urban agglomeration development, when redistribution of inhabitants and places of work, ap- 
pearing through their more rapid growth in the suburban zone than in the central city of the agglomeration (urban life-cycle model). This aspect of suburbanisation is proper already for a higher stage of development of an agglomeration.

A symptom of the consecutive stage of suburbanisation may be constituted by the so-called "exurbanisation", that is - the urbanisation of the territories adjacent to the former suburban zone, which has been gradually taking over many of the negative characteristics, proper for the central city in the past. In fact "exurbanisation" seems to bind all three mentioned meanings of suburbanisation (urbanisation of green areas, movement to edge cities, growth rates higher than in central city and older suburbs).

\section{THE SPECIFICITY OF THE SUBURBANISATION IN WARSAW}

In Poland, in the period of relatively low level of urbanisation of the country and the wide disparity between the urban and rural areas, the process of suburbanisation was identified with the process of transformation of the rural areas, neighbouring upon large towns, into the urban areas. Yet in the 1980s a scientific debate was going on whether suburbanisation is a diffusion of "progress" into the rural areas from the large towns, or just a symptom of the universal process of modernisation in the course of economic growth process, steered by the state (Węgleński, 1983). On the one hand this process meant an increase of the numbers of people and apartments, as well as businesses, and the decrease of agricultural areas turned over to more intensive forms of land use, the change of the previously dominant life style of the inhabitants and of the physiognomy of structures. On the other hand it was the process of transformation of the settlements located outside of the central city through their integration with this central city in the spheres of employment (job commuting), use of municipal service, and taking over of some of the central city functions (storage, waste dumps, recreation). In fact up to the 1980 s, identification of the suburbanisation process with modernisation allowed for only a very meagre degree of recognition of the negative consequences of this process (urban sprawl).

Agglomeration economies and limited resources for the development of housing and social infrastructure resulted altogether in location of new jobs and apartments primarily in Warsaw. Implementation of this kind of policy was secured by the monopolisation of employment (creation of new workplaces) and of housing construction by the state. A complementary means of control on the availability of jobs and apartments was constituted by the immigration quota (valid until 1984). Consequently, although until 1978 a quicker growth of the population numbers was observed in Warsaw, the population growth in the outer zones of the agglomeration was not far behind.

In the North American and Western European cities the process of accelerated suburbanisation - in the middle of the $20^{\text {th }}$ century - was generally being associated with the outflow of the more well-off inhabitants towards the suburban zone away from the central city. In the agglomeration of Warsaw this outer zone had been until the 1970s first of all the "promise land" for the poorer immigrants from around the country, seeking jobs in Warsaw. This is not to say, of course, that there have not existed definite enclaves (like Podkowa 
Leśna, Konstancin, Otwock), featuring an attractive microclimate, inhabited partly by the wealthy population. Consequently, yet in the 1970s the socio-spatial structure of the Agglomeration of Warsaw reflected, in principle, the setting known from the Sjoberg's pattern of the pre-industrial city (Węcławowicz, 1988).

High land prices and apartment rents in the central city caused that the rate of growth of the population number was higher there during the entire first half of the $20^{\text {th }}$ century than in Warsaw itself. In the centrally managed economy, after the World War II, the lowskilled workers, flowing into the agglomeration, ensured for themselves the source of upkeep in Warsaw at the cost of burdensome commuting and a low standard of life in the localities of the suburban zone. The suburban zone had been displaying until the transition to the market economy a significant shortage of apartments in comparison with the number of households and a high share (more than 1/5 in 1988) of dwellings devoid of the basic installations. At the moment of the systemic transformation the situation was better with this respect not only in Warsaw, but also on the average in the country, both in urban and in the rural areas (Gałąza, 1998).

The period of 1978-1988 featured a relative decentralisation of Warsaw, although the rate of growth of the suburban zone was only slightly higher than that of the central city (Lisowski, 2002). It was only in the 1990s that Warsaw entered the phase of absolute decentralisation due to the decrease of population number in the central city and the persisting rather modest growth of the suburban zone (growth rate of the population $0.6 \%$ per year), and rather stagnation of the overall urban area (growth rate $0.04 \%$ per year). The advantages from settling in the suburban zone are still being shared by the most mobile persons from Warsaw with the newcomers from other parts of the country. In 1995, 60\% of the population leaving permanently Warsaw would settle in the entire suburban zone of Warsaw, but they constituted only $40 \%$ of the total of the population flowing into the suburban zone of the agglomeration (Potrykowska, Śleszyński, 1999).

The question of conditions for the suburbanisation process in the sense of redistribution of population and jobs in the urban agglomeration has a very rich literature, and the various classifications of its causes (Walker 1981; Mieszowski, Mills 1993; Bourne 1996). The process of suburbanisation of Warsaw in the 1990s has, as well, its specific features. Introduction of the market economy brought about essential changes in the conditions of activity of the population and businesses interested in settling in the suburban zone. Certainly, the most important changes from the point of view of the process of suburbanisation were as follows:

1. Bringing back the land rent.

2. Increase of differentiation of incomes of the population.

3. Privatisation of economy and commercialisation of housing.

4. Changes in organisation and technology of production and service (smaller private

5. firms, with much more flexible location behaviour).

6. Popularisation of passenger car as the transport means (380 cars per 1000 inhabitants in 2000).

Decentralisation of administration and a lack of co-ordination of spatial planning and fiscal policy on the local level. 
Differentiation of incomes, privatisation of economy and commercialisation of housing, and popularisation of the car, created altogether the possibility of choosing the most useful location of residence or of business activity, according to the convictions of the respective agents. The conviction that residence and the conduct of economic activity are cheaper in the suburban zone resulted from the rules of functioning of the land rent, supported by the preferential policy of the local authorities in the suburban zone, which gained broad freedom of shaping the spatial development and fiscal policy within the respective territories.

Table1: Distribution of population and businesses in the Warsaw Agglomeration 1995-2001

\begin{tabular}{|l|r|r|r|r|r|r|}
\hline \multirow{2}{*}{ Area } & \multicolumn{2}{|c|}{ Population (thou.) } & \multicolumn{2}{c|}{ Businesses (totals) (thou.) } & \multicolumn{2}{c|}{$\begin{array}{c}\text { Businesses with share } \\
\text { of foreign capital }\end{array}$} \\
\cline { 2 - 7 } & 1995 & 2001 & 1995 & 2001 & 1995 & 2001 \\
\hline Warsaw & 1635.1 & 1609.8 & 166.5 & 247.4 & 7268 & 13635 \\
\hline Ring & 781.5 & 825.5 & 55.6 & 96.1 & 705 & 1869 \\
\hline Agglomeration & 2416.6 & 2435.3 & 222.1 & 343.5 & 7922 & 15504 \\
\hline
\end{tabular}

Source: own calculation on the base of the Bank of Local Data, Central Statistical Office.

The share of Warsaw city in total population of agglomeration decreased in the period under study (1995-2001) from $67.7 \%$ to $66.1 \%$. Similarly as in the case of population, decreased its share in the number of businesses, from $74.6 \%$ to $72.1 \%$, and in terms of business units with foreign capital - from $91.2 \%$ to $87.9 \%$ (Table 1 ).

However there are opposed group of factors motivating the maintenance of the centralisation process in Warsaw agglomeration (its migration balance is still positive). The following factors counteract the depopulation of the central city:

a) The hardships of commuting (low capacity of the entry and exit roads, low carrying capacity of the municipal transport).

b) The extensive character of urban development and the possibility of locating new workplaces and dwellings within the confines of the city.

c) High cost of a house-with-a-garden, and even of an apartment, in comparison with the average incomes.

d) Perception of living conditions in central city as relatively satisfactory (lack of the inner city problems, relatively low share of the ethnic minorities) in relation to many parts of the suburban zone (low standards of the municipal infrastructure, higher unemployment).

\section{THE CHANGES IN THE LIVING CONDITIONS IN THE AGGLO-MERATION OF WARSAW}

The evaluation of the living conditions was performed with the use of ten indicators, reflecting five different aspects of the conditions of living of the population inhabiting the agglomeration, namely: personal incomes, housing conditions, social infrastructure, technical 
infrastructure, and environmental protection. Each of the aspects listed was described with two indicators, that is: the revenues (in Polish new zlotys, PLN) of the local authorities from the personal income tax per inhabitant, the share of the inhabitants of the municipal housing late in rent payment (\%), the number of dwelling units per 1,000 inhabitants, useable floor space of a dwelling per person (in sq. $\mathrm{m}$ ), the number of inhabitants per one medical dispensary, the number of pupils per one classroom in the primary schools, the density of communal roads per $100 \mathrm{sq}$. km, the density of sewage network per $100 \mathrm{sq}$. km, water consumption by the households (in cu. m), the share of population serviced by the se-wage treatment plants (\%).

The indicators obtained through the reduction of the initial set of variables were characterised by a sufficient variability (coefficient of variability exceeding $10 \%$, except for one variable $-9 \%$ ), and displayed low degree of correlation (maximum correlation coefficient equal 0.7$)$.

The changes of these indicators in the years 1995-2001 had a positive character, except for the delays in rent payment for the municipal flats (there has been a slight increase of the share of inhabitants late with their payments outside of Warsaw). It is worth emphasising that the increase of consumption of water from the water supply systems in the suburban zone was accompanied by a constant decrease of water consumption in Warsaw, since in the 1990s water meters were commonly installed. The spatial differentiation in the agglomeration increased in the period analysed with respect to the following indicators of living conditions: personal incomes, number of dwellings per 1,000 inhabitants, as well as useable floor space of dwellings per person, while in the remaining categories the differentiation decreased, and especially so in the domain of environmental protection.

The individual territorial units of the agglomeration (47 communes of the suburban zone and Warsaw itself) were ascribed ranks in terms of each of the indicators. Using the methodological suggestion of G. M. Lewis (1968) the summary rank indicator of the living conditions was calculated then for each of the spatial units. The values of this summary indicator range in principle between 0 and 100. The higher the value - the better the conditions of living. Fig. 1 shows the thus assessed living conditions in the agglomeration of Warsaw in 2001.

In both time instants considered Warsaw displayed the best living conditions of the population, its position having even strengthened in 2001. Yet, the average value of the summary indicator for Warsaw (74 in 1995 and 80 in 2001) is only by 12 score points higher than for the best commune (Wesola) of the suburban zone (2001). Warsaw acquired the highest $\left(1^{\text {st }}\right)$ rank in just one case - the number of dwellings per 1,000 inhabitants (although the shortage of apartments is still estimated at some 40 thousand).

The highest indicators of living conditions characterised also the communes located in the neighbourhood of Warsaw (Piaseczno, Łomianki, Wesoła), and along some of the exit roads from the city (Michałowice, Nadarzyn). The lowest values of the living conditions indicators were observed mainly in the peripheral communes, especially in the North-west, where the Kampinos Forest National Park is located, along with its buffer zone. The differentiation of the living conditions in the agglomeration is quite strongly correlated with one of the indicators - the revenues of the local authorities from the personal income taxation (rank correlation coefficient equal 0.7). 
Figure 1: Level of the living conditions in the Agglomeration of Warsaw (2001) (see: p.10)

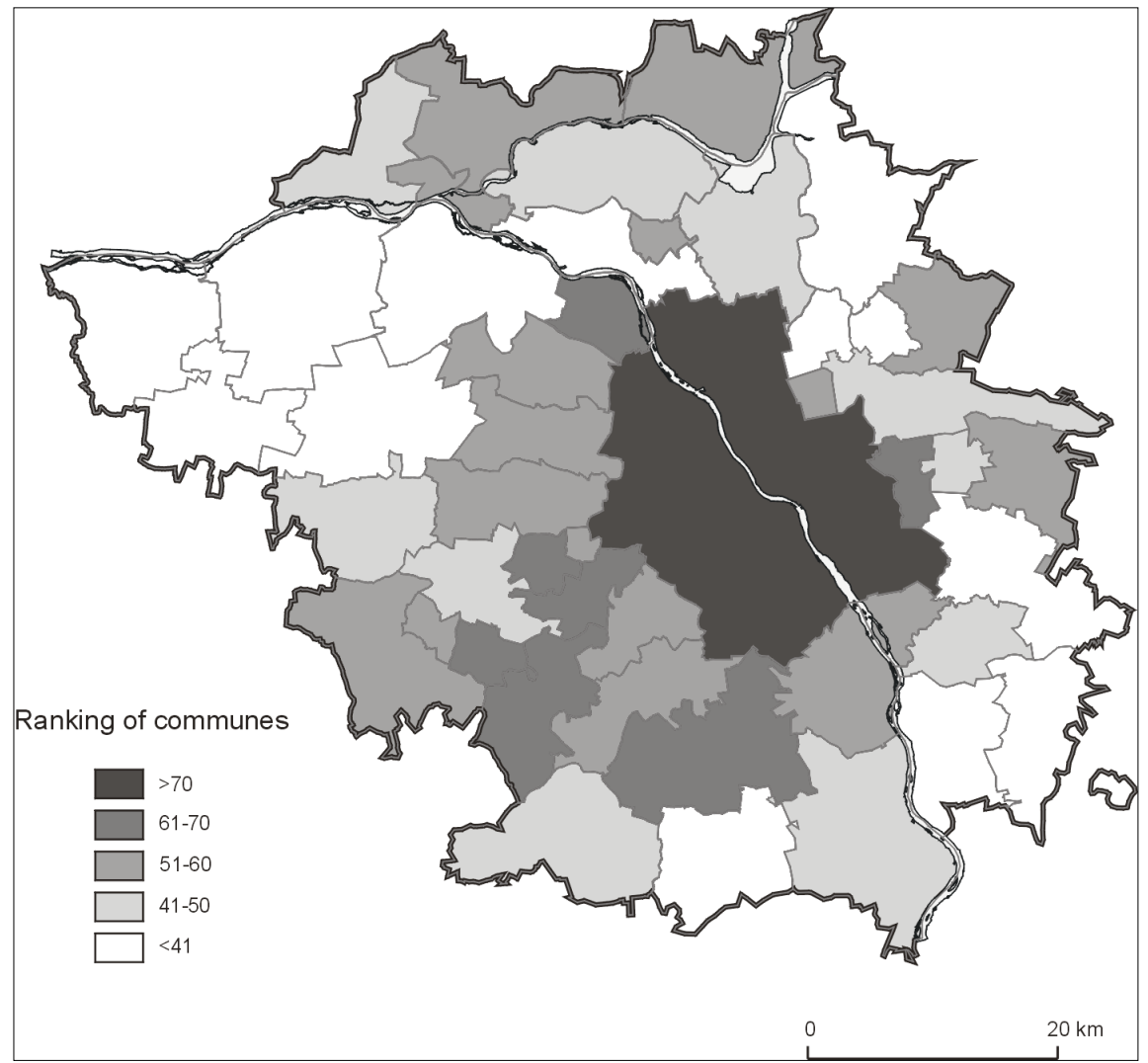

Despite the short period taken in the study some essential changes in the living conditions of the population inhabiting the agglomeration have taken place during the period. Namely, 19 spatial units had a higher summary rank in 2001 than in 1995, while almost all of the remaining ones dropped in the summary ranking (in case of two communes their positions did not change). Outside of Warsaw, in the years 1995-2001, the share of population inhabiting the rural territorial units, which featured the better living conditions (with scores more than 50 points) increased (from $15.1 \%$ to $18 \%$ ) in 2001, while the share of population living in better conditions decreased in the urban-rural communes and urban communes .

The living conditions of the population in the particular units of the agglomeration had an impact on the rate of growth of the population and businesses in the period of study. This applies in a particular manner to the rate of growth of the number of population and business units with share of foreign capital.. Thus, the share of population in the spatial units featuring higher values of the living conditions increased from $61.9 \%$ to $62.6 \%$, while the share of population in these units - from $61.9 \%$ to $62.6 \%$. In the case of economic agents with participation of foreign capital, their share in the communes characterised by the better living conditions increased from $76.3 .2 \%$ to $79.2 \%$ (Table 1 and Table 2). 
Table 2: Changes in the distribution of the numbers of population and businesses in relation to the living conditions in suburban communes in Warsaw Agglomeration 1995-2001

\begin{tabular}{|l|r|r|r|r|r|r|}
\hline \multirow{2}{*}{$\begin{array}{l}\text { Suburban } \\
\text { communes }\end{array}$} & \multicolumn{2}{|c|}{ Population (\%) } & \multicolumn{2}{c|}{$\begin{array}{c}\text { Businesses (\%) } \\
\text { (totals) }\end{array}$} & \multicolumn{2}{c|}{$\begin{array}{c}\text { Businesses with share } \\
\text { of foreign capital (\%) }\end{array}$} \\
\cline { 2 - 7 } & 1995 & 2001 & 1995 & 2001 & 1995 & 2001 \\
\hline $\begin{array}{l}\text { Communes with better } \\
\text { living conditions }\end{array}$ & 61.9 & 62.6 & 68.94 & 66.8 & 76.3 & 79.2 \\
\hline $\begin{array}{l}\text { Communes with worse } \\
\text { living conditions }\end{array}$ & 38.1 & 37.4 & 31.1 & 33.2 & 23.7 & 20.8 \\
\hline Communes (totals) & 100.0 & 100.0 & 100.0 & 100.0 & 100.0 & 100.0 \\
\hline
\end{tabular}

Source: own calculation on the base of the Bank of Local Data, Central Statistical Office.

The units, which went up the ranking in terms of living conditions in the years 1995-2001, displayed a higher increase of the population numbers in comparison with the units, whose ranks in the same classification went down. Yet, no such regularity was observed in the case of businesses. It was only in the case of unit with foreign capital that high dynamics was observed in the communes having improved their position in terms of living conditions in the period studied (Table 2). It is interesting to note that the highest increase of the number of businesses was observed in the communes featuring low level of living conditions (181\% as compared to $100 \%$ in 1995) as well as displaying a relative decrease of living conditions $1995-2001$ (173\% as compared to $100 \%$ in 1995$)$.

Table 3: Changes in the distribution of the numbers of population and businesses in relation to the relative changes of living conditions in suburban communes in Warsaw Agglomeration

\begin{tabular}{|l|r|r|r|r|r|r|}
\hline \multirow{2}{*}{ Suburban communes } & \multicolumn{2}{|c|}{$\begin{array}{c}\text { Population } \\
\text { (\%) }\end{array}$} & \multicolumn{2}{c|}{$\begin{array}{c}\text { Businesses } \\
\text { (\%) (totals) }\end{array}$} & \multicolumn{2}{c|}{$\begin{array}{c}\text { Businesses with a share } \\
\text { of foreign capital (\%) }\end{array}$} \\
\cline { 2 - 7 } & 1995 & 2001 & 1995 & 2001 & 1995 & 2001 \\
\hline $\begin{array}{l}\text { Communes displaying relative } \\
\text { improvement of living conditions }\end{array}$ & 37.0 & 37.6 & 41.4 & 40.1 & 51.8 & 57.2 \\
\hline $\begin{array}{l}\text { Communes displaying relative } \\
\text { decrease of living conditions }\end{array}$ & 63.0 & 62.4 & 58.6 & 59.9 & 48.2 & 42.8 \\
\hline Communes (totals) & 100 & 100 & 100 & 100 & 100 & 100 \\
\hline
\end{tabular}

Source: own calculation on the base of the Bank of Local Data, Central Statistical Office.

Although one can hardly deny the essential role of the living conditions of the population in the shaping of redistribution of population and businesses in the agglomeration in the years 1995-2001, one should remember the factors mentioned before, which limit the scope of the process. The town planners do as a rule agree that the inadequate capacity of the transport system of the entire agglomeration constitutes the problem requiring a possibly rapid solution. This applies both to the entry and exit roads to/from the central town, and to the municipal transport. The state of the roads and the conditions of traffic should be conside- 
red the most neglected sphere of urban economy against the background of other European capitals (Gawryszewski et al., 1998).

Interesting results were obtained by comparing the rate of growth of the numbers of population and businesses in the years 1995-2001 with the location of spatial units in the Agglomeration of Warsaw. It turned out that the role of this factor in the processes of population and job redistribution is more important than the role of the living conditions (Table 3). The rate of growth of the population numbers in the communes neighbouring upon Warsaw was distinctly higher not only in comparison with the outer communes, but also than in the communes featuring the highest levels of living standards of the population and the rates of their growth. The same zone showed also a higher rate of growth of the number of businesses with a share of foreign capital (303\% as compared in 1995) than the communes displaying an improvement in the living conditions of the population on the scale of the agglomeration (293\%), and still decidedly higher than the communes with better living conditions (276\%).

Table 4: Changes in the distribution of the numbers of population and businesses in relation to the location of suburban communes in Warsaw Agglomeration 1995-2001

\begin{tabular}{|l|r|r|r|r|r|r|}
\hline \multirow{2}{*}{ Suburban communes } & \multicolumn{2}{|c|}{ Population (\%) } & \multicolumn{2}{|c|}{$\begin{array}{c}\text { Businesses (\%) } \\
\text { (totals) }\end{array}$} & \multicolumn{2}{|c|}{$\begin{array}{c}\text { Businesses with } \\
\text { share of foreign } \\
\text { capital (\%) }\end{array}$} \\
\cline { 2 - 7 } & 1995 & 2001 & 1995 & 2001 & 1995 & 2001 \\
\hline Communes located close to Warsaw & 31.8 & 33.8 & 47.8 & 42.5 & 60.4 & 69.1 \\
\hline Other communes & 68.2 & 66.2 & 52.2 & 57.5 & 39.6 & 30.9 \\
\hline Communes (totals) & 100.0 & 100.0 & 100.0 & 100.0 & 100.0 & 100.0 \\
\hline
\end{tabular}

Source: own calculation on the base of the Bank of Local Data, Central Statistical Office.

\section{CONCLUSIONS}

The results obtained, even though acquired through the use of quite simple statistical techniques, confirm the results of other studies (Potrykowska, Śleszynski, 1999). The population migrating from Warsaw and flowing into the agglomeration seeks new places of residence closer to the boundaries of the central town in view of the hardships of commuting and/or compensation of the lack of some basic facilities beyond the city boundaries. It appears that this issue plays a more important role than the actual living conditions in the respective communes, although it so happens that out of 18 communes only five (Jabłonna, Wiązowna, Nieporęt, Zielonka and Marki) feature living conditions scores below 50 points, all of them being located on the eastern bank of Vistula river.

It is interesting to note that the increase of the number of new businesses was slightly higher in these spatial units, which have not shown better living conditions and a distinct relative improvement of the living conditions of the population in the years 1995-2001 (Table 1 and Table 2). The question of closeness to Warsaw does not play a significant role too. The growth of the number of businesses was the highest in the communes located 
beyond the communes close to Warsaw (186\% as compared $100 \%$ in 1995). Probably this fact suggests that the selection of locations for the conduct of smaller businesses (labour intensive) is being done with different criteria than the selection of the locations of larger firms.

Available data on employed persons by actual workplace (excluding firms employing up to 5 persons) in the 1990s (1992-1997) confirmed that the rate of growth of the number of jobs was higher (11.1\% per year) in the suburban zone close to Warsaw than in the external zone $(5.8 \%)$. The increase of business units with share of foreign capital confirms an inflow of larger firms to the areas neighbouring upon Warsaw. Many new shopping complexes were established in this zone by foreign contractors in the late 1990s.

In Poland, the businesses employing up to 5 persons accounted over $50 \%$ of all registered economic agents in the years 1993-1995 (Nowosielska, 2000). Trade and repair, construction, transport and storage mainly participated (over $50 \%$ ) in the total growth of the number of the businesses in outer suburban zone 1995-2001.

The border area seems to be too competitive environment, especially for smaller businesses (at the same time attractive residential area, the higher costs of land and higher taxes), but reference to the sheer numbers of businesses (all registered economic agents) provides just a definite approximation of the process of redistribution of jobs, since more unambiguous results could only be gained from the data on employment. Partial information and the changes in the manner of aggregating employment data in Poland constitute a great problem for the studies of this question in the spatial setting.

\section{References}

Bourne, L., S., 1996: Reinventing the suburbs: old myths and new realities. Progress in Planning, 46, 3, p. 163-184.

Champion, A. G., 2001: Urbanization, suburbanization, counterurbanization and reurbanization. V: Paddison R., (ed.) Handbook of urban studies, London-Thousand OaksNew Delhi, Sage Publications, p.143-161.

Gałązka, A., 1998: Housing situation of the population of Warsaw agglomeration in the years 1970-1988. Spatial differentiation and change tendencies. Prace Geograficzne IGiPZ PAN, 169 (in Polish).

Gawryszewski, A., Korcelli, P., Nowosielska, E., 1998: Metropolitan functions of Warsaw. Zeszyty IGiPZ PAN, 53, (in Polish).

Johnston R.,J., Gregory, D., Pratt G., Watts M., 2000: The dictionary of human geography . Oxford-Malden Mass., Blackwell Publishers.

Lewis, G.,M., 1968: Levels of living in the North-eastern United States c. 1960: A new approach to regional geography. Transactions, Institute of British Geographers, 45, p. 11-37.

Lisowski, A. 2002: The model of urban life-cycle and the metropolitan area of Warsaw. Perspectives on Urban Spheres, Conference of International Geographical Union Urban Commission (19), Pretoria, South Africa (mimeo.).

Mieszowski, P., Mills, E., 1993: The causes of metropolitan suburbanisation. Journal of Economic Perspectives, 7, p. 135-147. 
Nowosielska, E., 2000: The service sector of Warsaw Agglomeration 1992-1997: structural changes and trends. Dokumentacja Geograficzna, IGiPZ PAN,17, (in Polish).

Potrykowska, A., Śleszyński, P., 1999: Internal migration in Warsaw and Warsaw voivodships, Atlas Warszawy, 7, IGiPZ PAN (in Polish).

Walker, R., 1981: A theory of suburbanization: capitalism and the construction of space in the United States. V: Dear, M., Scott, A., (eds.) Urbanisation and urban planning in capitalist society, New York, Methuen, p. 383-430.

Węcławowicz, G., 1988: Socio-spatial structures in Polish cities. Prace Habilitacyjne, IGiPZ PAN, Warszawa -Wroclaw, Ossolineum (in Polish).

Węgleński, J., 1983: Urbanisation: a controversy over notion. Warszawa, Państwowe Wydawnictwo Naukowe (in Polish). 